Both foci lie close to the great are of Sumatra, Java, Sumbawa, Flores, etc., along which many other earthquake centres, deep-seated and otherwise, are clustered.

\section{Association for Physical Medicine}

THIs society was inaugurated on January 27 at 56 Russell Street, W.C.1, with Dr. P. Dalton in the chair. The aims of the Society are : (1) To co-ordinate the various branches of physical medicine under one control ; (2) to co-operate with manufacturers in the production of suitable appliances for medical and surgical use, and to prevent their sale to unsuitable persons; (3) to secure a national register of those practising the science and to affiliate all appropriate bodies; (4) to institute a chair of physical medicine in one or more of the universities and to establish a post-graduate school; (5) to establish contact with the general practitioner and to keep him informed of the changes in the subject; (6) to establish a technical board to act in an advisory capacity.

\section{Announcements}

ON February 12, two men of science of international reputation celebrate their birthdays. Prof. W. B. Scott, emeritus professor of palæontology in Princeton University, is eighty years of age; and Prof. Otto Pettersson, the Swedish chemist and oceanographer, is ninety years on that date. They may be assured that they have the congratulations and best wishes of scientific workers everywhere.

Tre fifteenth Duddell Medal of the Physical Society has been awarded to Prof. H. Geiger, professor of physics in the University of Tübingen.

THE triennial award of the Coopers Hill War Memorial Prize and Medal, which fell in 1937 to the Institution of Electrical Engineers, has been made to Dr. T. E. Allibone for his paper on "The Mechanism of the Long Spark".

THE Council of the Institution of Civil Engineers has made the first award of the James Alfred Ewing Medal to Mr. Charles Samuel Franklin. This medal was founded in 1936 in memory of Sir Alfred Ewing, and is awarded, irrespective of membership of the Institution, for specially meritorious contributions to the science of engineering in the field of research.

Prof. W. P. Jorissen, of the University of Leyden, will deliver a lecture entitled "Reactions in Gaseous and Solid Mixtures", in the Chemistry Lecture Theatre of the Imperial College of Science and Technology, on February 21, at 5.15 p.m. Admission to the lecture is free.

FIve lectures on science and industry have been arranged by the Association of Scientific Workers, to be given in the Chemistry Theatre, University College, London. The lectures are as follows:
February 16, Sir Richard Gregory on "Science and Industry"; February 24, Sir John Russell on "The Application of Science to Food Production"; March 2, Major F. A. Freeth on "Science and the Chemical Industry"; March 9, Dr. E. A. Rudge on "Training for Industry"; March 17, Dr. F. S. Sinnatt on "The Fuel Research Survey". The lectures will be given at 8.15 p.m. Tickets are obtainable from the Secretary, Association of Scientific Workers, 28 Hogarth Road, London, S.W.5, free to members and 1s. $6 d$. to non-members for the series, or $6 d$. for a single lecture.

AT the annual general meeting of the National Institute of Sciences of India, held on January 8, the following were elected officers : President, Prof. M. N. Saha ; Vice-Presidents, Prof. S. S. Bhatnagar and Brevet:Colonel R. N. Chopra; Treasurer, Dr. B. S. Guha; Foreign Secretary, Prof. B. Sahni; Secretaries, Prof. S. P. Agharkar and Dr. A. M. Heron.

The Medical Research Council has been entrusted with an annuity of $£ 350$ for a period of twenty-five years, provided by the late Mr. Eugen M. Schlesinger and by Mrs. Schlesinger to establish a memorial to their daughter in the form of a Kathleen Schlesinger Research Fellowship. This is to be given for investigations on the subject of cysts of the brain or allied conditions, and will ordinarily be tenable at the National Hospital for Diseases of the Nervous System, Queen Square, London, for periods of from one to three years. Awards will be made by the Council with the assistance of a special advisory committee appointed in terms of the trust deed.

Dr. Eugen Fischer, professor of anthropology in the University of Berlin, and Dr. Hermann Lautensach, professor of geography at Greifswald, have been nominated for honorary doctorates of the University of Coimbra.

The annual congress of the German Society of Balneology and Climatology will be held at Kiel on February 24-27. Further information can be obtained from Dr. Pfleiderer, Tirpitzstrasse 12, Kiel.

THE fortieth Congress of the German Zoological Society will be held at Giessen on July 4-6, 1938. Further information can be obtained from the Secretary of the Society, Invalidenstrasse 43, Berlin, N.4.

Dr. G. D. Bhalerao, helminthologist of the Imperial Veterinary Research Institute, MuktesarKumain, India, is to prepare a volume in the "Fauna of British India" on Trematoda.

IN the article entitled "Museum Study of Man and his Work" in NaTuRE of December 25 (p. 1108), reference is made to the Colonial Institute at Haarlem. This is incorrect; the Colonial Institute is at Amsterdam. 